\title{
Agromorphological Traits and Mineral Content in Tomato Accessions from El Salvador, Central America
}

\author{
José Luis Chávez-Servia ${ }^{1, *}$ (iD), Araceli Minerva Vera-Guzmán ${ }^{1}$ (iD, \\ Lesser Roberto Linares-Menéndez ${ }^{2}$, José Cruz Carrillo-Rodríguez ${ }^{3}$ \\ and Elia Nora Aquino-Bolaños ${ }^{4}$ \\ 1 Instituto Politécnico Nacional, CIIDIR Unidad Oaxaca, Oaxaca 71230, Mexico; avera@ipn.mx \\ 2 Centro Nacional de Tecnología Agropecuaria y Forestal, La Libertad 1511, El Salvador; \\ lesserlinaresss@hotmail.es \\ 3 Instituto Tecnológico del Valle de Oaxaca, Oaxaca 71230, Mexico; jcarrillo_rodriguez@hotmail.com \\ 4 Instituto de Ciencias Básicas, Universidad Veracruzana, Jalapa 91192, Mexico; eliaquino@uv.mx \\ * Correspondence: jchavezs@ipn.mx; Tel.: +52-951-517-0610
}

Received: 18 January 2018; Accepted: 9 March 2018; Published: 14 March 2018

\begin{abstract}
The agromorphological traits and phenotypic variation of mineral content in the fruit were evaluated in eleven tomato accessions from nine communities in El Salvador. The tomato collection was cultivated in a greenhouse with a randomized complete block design with three replications. Plant phenological and fruit traits, as well as the mineral content, were evaluated using atomic-absorption and ultraviolet-visible spectroscopy. In the analysis of variance, significant differences $(p<0.01)$ among the accessions were determined for agromorphological traits and all mineral elements except $\mathrm{Cu}$. Plant height at 30,60 and 90 days after transplant, days to flowering and maturating of the fruits, and the number and weight of fruits per plant were useful variables for describing the phenotypic divergences among the tomato accessions. In terms of mineral content, the differences among the accessions were based on $\mathrm{Mg}, \mathrm{P}, \mathrm{S}, \mathrm{Fe}, \mathrm{Zn}$ and $\mathrm{Mn}$. The weights of the fruits per cluster and per plant and fruit weight presented negative correlations with $\mathrm{Ca}, \mathrm{Mg}, \mathrm{Fe}$ and $\mathrm{P}(\mathrm{r}=-0.67$ to $-0.71, p<0.05)$ and a positive correlation with $\mathrm{Na}(0.63)$.
\end{abstract}

Keywords: Solanum lycopersicum; phenotypic variation; landraces; spectrophotometry; micro and macro-minerals

\section{Introduction}

Wild tomato (S. lycopersicum $=$ S. lycopersicum var. cerasiforme) populations follow adaptive life strategies as ruderal plants in the Americas, because they usually grow in natural or disturbed lands such as roadsides, backyards, cultivated and deforested lands, dispersed by birds and without human care. Wild tomato accessions range from the southeastern United States to South America, and they originate along the coast of Ecuador, Peru, part of Bolivia and the northern region of Chile [1-4]. In these countries, there is significant genetic diversity of Solanum lycopersicum L. and wild species; however, tomato producers and breeders from agricultural research centers tend to introduce hybrids and improved varieties to boost fruit quality and crop performance [5,6]. In traditional production systems, the tomato landraces were chosen by farmers based on varieties that had been introduced many years ago through natural hybridization or from the crossing of improved varieties and wild tomato plants growing close to crop fields [2,7-9].

Central and South American wild tomato differs substantially from processing tomato (commercial types) in terms of fruit size and weight, plant yield, and productivity per hectare. Cherry tomato presents high variability in terms of fruit qualities such as flavor, aroma, color, texture and bioactive compounds such as lycopene [10,11], but its vitamin and mineral content is less 
well-documented [12]. Fernandez-Ruiz et al. [13] found lower mineral contents in cultivated varieties of S. lycopersicum than in wild species such as S. pimpinellifolium, S. cheesmaniae, and S. habrochaites. Guil-Guerrero and Rebolloso-Fuentes [14] found that cherry tomato frequently had a higher Mn, $\mathrm{Fe}$ and $\mathrm{Zn}$ content than traditional and commercial tomato varieties with larger fruits.

Wild tomato (S. lycopersicum var. cerasiforme) with cherry fruit needs broad characterization to determine the value of its use and to propose strategies for its rational exploitation in the future to solve local problems such as agronomic adaptation to climatic changes or, in nutritional terms, to promote its consumption as a functional food. There is currently a debate surrounding the tomato regarding the association or link between its agronomic traits and fruit composition [15]. Cherry fruits are commonly used in diverse ways, including raw in salads and processed, and their acidity allows for ease of preservation without refrigeration (long shelf life) or home canning processing for later use [16]. Given these considerations of use, wild accessions and cultivated landraces of tomato from El Salvador are a genetic source of diversity and can be useful to complement the mineral requirements for human health.

Despite the existing range of genepools of introduced and native tomatoes that can be used as precursors for improved varieties in several Latin American countries [17,18], a limiting factor is the incomplete description of their agromorphological, phenotypic, genetic and biochemical variability, as well as information regarding the evaluation of the effects of biotic and abiotic stress. In several cases, traditional tomato landraces, which farmers continue to farm on their lands, cannot be assumed to be homogenous and genetically uniform, even though the same fruit shapes can be observed $[9,19,20]$. Each variety preserved by one or more farmers can be deemed to be a subpopulation with high levels of genetic differentiation [21]. This is why it is important to characterize the different genepools of the Latin American tomato by focusing on the fruit [22], tolerance to abiotic $[23,24]$ and biotic stress $[25,26]$, phenotypic and genetic diversity $[27,28]$, performance stability or genotype-environmental interaction [5,6], and even aspects relating to consumer preference [29] in order to describe the phenotypic and genetic diversity of the tomato. In terms of the genepools found in El Salvador, studies on phenotypic and genetic diversity are difficult to find or do not exist.

Furthermore, several research projects have focused on evaluating the lycopene, flavonoid, carotenoid, polyphenol and other secondary metabolite contents in tomato fruits, which have been shown to present high antioxidant activity [30,31]. However, in terms of the composition of the fruit itself, relatively little research has been conducted to quantify the variation of mineral content and the variation as a result of genetic, environmental, and crop and post-harvesting handling effects [12,32-36]. Improved varieties were used in all previous studies of fruit composition and agronomic valuations, and very few have been focused on evaluating trace mineral contents in the fruits of old landraces, wild populations and wild species, or how this information could be used for genetic improvement purposes. Furthermore, this information is important in proposing improvements to the diets of both rural and urban communities.

The agromorphological and biochemical characterization of tomato genepools will help formulate genetic diversity conservation and genetic improvement strategies by setting focused goals and objectives that benefit both local farmers and consumers. The objective of this research was to describe the agromorphological traits and mineral content in fruits from a collection of tomatoes from El Salvador that were cultivated in a greenhouse.

\section{Materials and Methods}

Germplasm. Eleven accessions of cherry-type and medium-sized flattened fruits were collected in the central region of El Salvador. The regions from which the accessions were collected vary between an altitude of 625 and 925 m.a.s.l., have a tropical climate with average temperatures of $22.9^{\circ} \mathrm{C}$, and receive 1800 to $1900 \mathrm{~mm}$ of annual rainfall (Table 1). For the purpose of this study, we considered each sample as a population, because each of them came from 3 to 10 plants; we assumed each to be a wild population, because of their origin; and we designated each sample as an accession. The populations 
of cherry-type tomato were collected from plants located along roadsides, in home backyards, and near the fences of crop fields-which can be considered a wild source-and the two accessions (LLMO1 and LLMO8) of medium-size flattened plants were collected in home backyards and near the fences of crop fields where tomato fields existed in previous years. In the last case, the collected accessions were considered to be local landraces because they grow 'spontaneously' (i.e., they are not planted) or are only semi-cultivated by farmers. All of the collected tomato germplasm became part of an active collection deposited in the experimental station of the Centro Nacional de Tecnologia Agropecuaria y Forestal (CENTA), from the La Libertad, El Salvador. On the basis of previous evaluations of the active collection and the experiences of the researchers from the CENTA, eleven accessions were selected that had agronomic potential and were preferred for consumption by the local population.

Table 1. Regions of origin for the characterized accessions of tomato from El Salvador, Central America.

\begin{tabular}{cccccc}
\hline $\begin{array}{c}\text { Population } \\
\text { ID }\end{array}$ & Fruit Type & $\begin{array}{c}\text { Region of Origin from El Salvador } \\
\text { (Municipality, Department) }\end{array}$ & $\begin{array}{c}\text { Latitude } \\
\mathbf{( N )}\end{array}$ & $\begin{array}{c}\text { Longitude } \\
\mathbf{( W )}\end{array}$ & $\begin{array}{c}\text { Altitude } \\
\text { (m.a.s.1.) }\end{array}$ \\
\hline LLM01 & Medium size & La Libertad, La Libertad & $13^{\circ} 29^{\prime} 18^{\prime \prime}$ & $89^{\circ} 19^{\prime} 14^{\prime \prime}$ & 637 \\
LLM02 & Cherry & San José Villanueva, La Libertad & $13^{\circ} 34^{\prime} 00^{\prime \prime}$ & $89^{\circ} 16^{\prime} 00^{\prime \prime}$ & 540 \\
LLM03 & Cherry & San José Villanueva, La Libertad & $13^{\circ} 34^{\prime} 00^{\prime \prime}$ & $89^{\circ} 16^{\prime} 00^{\prime \prime}$ & 540 \\
LLM04 & Cherry & San Juan Opico, La Libertad & $13^{\circ} 52^{\prime} 60^{\prime \prime}$ & $89^{\circ} 21^{\prime} 00^{\prime \prime}$ & 522 \\
LLM05 & Cherry & San Salvador, San Salvador & $13^{\circ} 41^{\prime} 24^{\prime \prime}$ & $89^{\circ} 11^{\prime} 24^{\prime \prime}$ & 649 \\
LLM06 & Cherry & San Pablo Tacachico, La Libertad & $13^{\circ} 58^{\prime} 60^{\prime \prime}$ & $89^{\circ} 19^{\prime} 60^{\prime \prime}$ & 307 \\
LLM07 & Cherry & Ciudad Victoria, Cabañas & $13^{\circ} 57^{\prime} 00^{\prime \prime}$ & $88^{\circ} 37^{\prime} 60^{\prime \prime}$ & 868 \\
LLM08 & Medium size & San Pablo Tacachico, La Libertad & $13^{\circ} 58^{\prime} 60^{\prime \prime}$ & $89^{\circ} 19^{\prime} 60^{\prime \prime}$ & 307 \\
LLM09 & Cherry & Ciudad Victoria, Cabañas & $13^{\circ} 57^{\prime} 00^{\prime \prime}$ & $88^{\circ} 37^{\prime} 60^{\prime \prime}$ & 868 \\
LLM10 & Cherry & Ciudad Victoria, Cabañas & $13^{\circ} 57^{\prime} 00^{\prime \prime}$ & $88^{\circ} 37^{\prime} 60^{\prime \prime}$ & 868 \\
LLM11 & Cherry & Ciudad Arce, La Libertad & $13^{\circ} 49^{\prime} 60^{\prime \prime}$ & $89^{\circ} 25^{\prime} 60^{\prime \prime}$ & 525 \\
\hline
\end{tabular}

Agromorphological characterization. The collection was planted and cultivated in a greenhouse during the summer-fall of 2011 in Santa Cruz Xoxocotlan, Oaxaca, Mexico $\left(17^{\circ} 1^{\prime} 10.42^{\prime \prime} \mathrm{N}\right.$, $96^{\circ} 45^{\prime} 52.32^{\prime \prime} \mathrm{W}$, at an altitude of 1561 m.a.s.1.), with variations in relative humidity from 30.6 to $79.1 \%$ and temperatures from 13.4 to $27.8^{\circ} \mathrm{C}$, averaging $36.7 \%$ and $25.6^{\circ} \mathrm{C}$, respectively. The seeds were germinated in commercial peat moss (Spaghnum sp.), and when the seedlings had 3 or 4 leaves, they were transplanted (12 July 2011) into disinfected soil that had been fertilized with 18-46-0 (diammonium phosphate) and potassium chloride. The eleven wild accessions of tomato were distributed in the greenhouse under a randomized complete block design with three replications, including an experimental plot of 10 plants. Fertilization was carried out using a drip irrigation system, two soluble triple-18 fertilizers, and calcium nitrate until the fruit took hold; potassium nitrate was then used for production. In the experimental design, we did not include controls based in the principle of phenotypic and genetic differentiation between cultivated landraces and contemporary tomato varieties demonstrated by SNP genotyping and fruit composition [37,38].

During the cultivation process, imidacloprid (Confidor $350 \mathrm{SC}^{\circledR}$ ), cypermethrin (Arrivo 200 $\left.C E^{\circledR}\right)$, and commercially available vegetable extracts such as $\operatorname{Viprot}^{\circledR}$, Exakint $^{\circledR}$ and Bio-crak ${ }^{\circledR}$ were used for pest-control purposes. To prevent and control disease, $\mathrm{N}$-trichloromethyl-4-cyclohexene1,2-dicarboximide (Captan $80^{\circledR}$ ), copper oxychloride (Cupravit Mix ${ }^{\circledR}$ ), copper sulfate, and Mancozeb (Manzate ${ }^{\circledR}$ ) were used.

To describe the phenotypic variation of the tomato accessions, 14 agromorphological variables were registered from the first stages of development until the physiological maturity of the fifth cluster of fruit, including the height of the plant 30,60 and 90 days after transplant (dat) for three plants per experimental plot; the number of flowers up until the fifth cluster; the number and weight of fruits per cluster and per plant up until the fifth cluster in three plants; the days after transplanting until the appearance of flowers, fruits and the maturity of fruits from the first cluster in more than $50 \%$ of the plants per experimental plot; and the average weight, length and width of the fruit in a sample of 15 fruits per experimental plot. These variables were recorded based on the descriptors of 
IPGRI, AVRDC and CATIE [39] and previous research [40,41], and they enabled the determination of the variation among the accessions with respect to growth type (indeterminate or determinate) and estimations of the precocity at first harvest and productivity per plant for each population.

Evaluation of mineral content in fruit. From the greenhouse experiment, fruit samples ranging from 300 to $500 \mathrm{~g}$ were harvested, crushed and refrigerated at $-20^{\circ} \mathrm{C}$ until their analysis in the laboratory. Ashes were obtained from each tomato population in accordance with method 975.03B (a) from the $\mathrm{AOAC}$ [42]. The ashes were dissolved in an acidic medium to extract the minerals $\mathrm{Cu}, \mathrm{Fe}, \mathrm{Mg}, \mathrm{Zn}$, $\mathrm{Na}, \mathrm{K}$, and $\mathrm{Ca}$ (mg/100 $\mathrm{g}$ of dry weight). Mineral content was determined using atomic absorption spectrophotometry (Thermo Scientific, Model PAL 3000) using lamps and calibration curves with specific standards (J.T. Baker ${ }^{\circledR}$ ) for each element (method 965.09, AOAC [42]). The $S$ and P contents were measured using a GBC visible-UV spectrophotometer (CINTRA model), and the $S$ values were recorded as $\mathrm{SO}_{4}$ content. Readings were taken in triplicate.

Statistical analysis. The data from the agromorphological variables and mineral content in the fruits were subjected to analysis of variance to test the differences among the accessions considering nesting of plants evaluated into the populations, and later a multiple Tukey's test $(p<0.05)$ was also used. After that, a Pearson's correlation was performed to determine a group of variables not significantly correlated $(p \leq 0.05)$ in both databases, then the averages for each accession were estimated and standardized as z-values for each variable, and then a principal component analysis (PCA) was performed using a variance-covariance matrix. The contribution of each variable to each principal component (= combination of variables and eigenvectors) was assessed as a function of the eigenvectors' values. With the same subgroup of variables used for the PCA, a hierarchical cluster analysis was done using Ward's method for agromorphological traits as well as mineral content. In the final phase, a Pearson's correlation analysis was conducted to test the relationships among the fruit traits and mineral contents, and we included only those correlations with significant values $(t$-test, $p \leq 0.05)$. All analysis was undertaken using SAS software.

\section{Results and Discussion}

In general, the results showed that nine accessions presented indeterminate growth and two presented determine growth, and the period 54 to 60 days after transplant saw the first harvests of ripened fruits and important quantities of mineral content in fruits. This is relevant in order to define alternative uses of wild cherry tomato, which is still unexploited or underexploited in Central and South America, despite easy access to its broadly distributed germplasm in tropical, subtropical and transition areas [43].

\subsection{Variation in Agromorphological Traits}

Significant differences among the accessions $(p<0.01)$ were found for all the agromorphological variables that were evaluated. In terms of the coefficient of variation, values varied between $3.1 \%$ and $13.1 \%$ (Table 2). These results reflect the fact that the accessions differ from one another in one or more of the characteristics evaluated, indicating phenotypic divergence. This indicates that there is unexplored and undocumented genetic diversity along the Pacific coast of El Salvador. For example, there are few representatives from the country (3) in the collection of the C. M. Rick Tomato Genetics Resource Center [44,45].

The tomato accessions evaluated from the regions of La Libertad and Cabañas, El Salvador presented phenotypic divergence in the phenological stages of flowering, fructifying and fruit maturation. Accessions LLMO2 and LLMO6 took longer to reach these stages, while the fastest accessions were LLMO8 and LLMO1. Despite these differences, from 20 to 29 days after transplant (dat), the plants flowered; from 35 to 39 dat, they reached the fructifying stage; and from 54 to 60 dat, the fruit ripened. In terms of plant heights, 30 days after transplant (dat), sizes varied from 19.7 to $28.1 \mathrm{~cm}$, but at 90 dat it ranged from 82.3 to $178.1 \mathrm{~cm}$. The LLMO1 and LLMO11 accessions did not grow more than $91 \mathrm{~cm}$ in height (Table 3). 
Table 2. Square means significance of agromorphological traits evaluated in eleven tomato accessions from El Salvador, Central America.

\begin{tabular}{cccccc}
\hline Variables Evaluated & \multicolumn{3}{c}{ Sources of Variations } & \multirow{2}{*}{ CV (\%) } \\
\cline { 2 - 5 } & Repetitions & Accessions & Plant (Acc.) ${ }^{2}$ & Error & \\
\hline Days to start of flowering ${ }^{1}$ & $118.91^{* *}$ & $43.76^{* *}$ & - & 4.23 & 8.7 \\
Days to start of fructifying ${ }^{1}$ & $4.45^{*}$ & $10.62^{* *}$ & - & 1.25 & 3.1 \\
Days to start of fruit maturating & $471.55^{* *}$ & $29.49^{* *}$ & - & 2.82 & 2.9 \\
Plant height at 30 dat ${ }^{1}$ & $88.86^{* *}$ & $59.91^{* *}$ & $7.07^{\mathrm{NS}}$ & 4.82 & 9.0 \\
Plant height at 60 dat ${ }^{1}$ & $749.72^{* *}$ & $332.94^{* *}$ & $42.29^{\mathrm{NS}}$ & 61.44 & 13.0 \\
Plant height at 90 dat ${ }^{1}$ & $18.40^{* *}$ & $22.15^{* *}$ & $2.49^{\mathrm{NS}}$ & 2.12 & 13.1 \\
Number of flowers per cluster & $0.49^{\mathrm{NS}}$ & $2.67^{* *}$ & $0.61^{\mathrm{NS}}$ & 0.48 & 8.7 \\
Number of fruits per cluster & $0.26^{\mathrm{NS}}$ & $1.82^{* *}$ & $0.61^{\mathrm{NS}}$ & 0.52 & 9.2 \\
Number of fruits per plant & $54.91^{*}$ & $46.79^{* *}$ & $11.96^{\mathrm{NS}}$ & 12.36 & 9.0 \\
Average weight of fruits per cluster & $0.006^{\mathrm{NS}}$ & $11.214^{* *}$ & $0.230^{\mathrm{NS}}$ & 0.43 & 11.2 \\
Average weight of fruits per plant & $0.03^{\mathrm{NS}}$ & $56.05^{* *}$ & $1.15^{\mathrm{NS}}$ & 2.16 & 11.2 \\
Average weight per fruit & $0.006^{\mathrm{NS}}$ & $11.214^{* *}$ & $0.230^{\mathrm{NS}}$ & 0.43 & 11.2 \\
Fruit length & $0.12^{* *}$ & $1.01^{* *}$ & - & 0.02 & 7.6 \\
Fruit width & $0.28^{* *}$ & $1.36^{* *}$ & - & 0.04 & 10.0 \\
\hline
\end{tabular}

${ }_{1}^{1}$ Days after transplant (dat); ${ }^{2}$ effect of plants nested in accessions, value absent means not applicable; NS,$*$ and ${ }^{* *}=$ not significant $(p>0.05)$, significant at $p<0.05$ and $p<0.01$, respectively; $C V=$ coefficient of variation.

Table 3. Mean comparisons of days to start of flowering, fructifying and maturating of fruits, and plant height in eleven tomato accessions from El Salvador.

\begin{tabular}{ccccccc}
\hline \multirow{2}{*}{ Pob. ID } & \multicolumn{2}{c}{ Days from Transplant to Start of } & \multicolumn{3}{c}{ Plant Height (cm) at } \\
\cline { 2 - 6 } & Flowering & Fructifying & Maturating & $\mathbf{3 0 ~ d a t}$ & $\mathbf{6 0}$ dat & $\mathbf{9 0}$ dat \\
\hline LLMO1 & $22.0 \mathrm{~cd}^{1}$ & $38.7 \mathrm{a}$ & $54.0 \mathrm{e}$ & $19.7 \mathrm{e}$ & $51.2 \mathrm{c}$ & $82.3 \mathrm{c}$ \\
LLMO2 & $25.7 \mathrm{ab}$ & $35.0 \mathrm{e}$ & $60.0 \mathrm{a}$ & $22.3 \mathrm{cde}$ & $55.2 \mathrm{bc}$ & $100.6 \mathrm{bc}$ \\
LLMO3 & $22.7 \mathrm{bcd}$ & $35.7 \mathrm{cde}$ & $57.3 \mathrm{bcd}$ & $26.3 \mathrm{ab}$ & $74.6 \mathrm{a}$ & $167.1 \mathrm{a}$ \\
LLMO4 & $23.7 \mathrm{bc}$ & $35.3 \mathrm{de}$ & $58.0 \mathrm{abc}$ & $25.1 \mathrm{abc}$ & $59.8 \mathrm{bc}$ & $100.6 \mathrm{bc}$ \\
LLMO5 & $23.7 \mathrm{bc}$ & $37.7 \mathrm{ab}$ & $59.0 \mathrm{ab}$ & $25.3 \mathrm{abc}$ & $56.2 \mathrm{bc}$ & $178.1 \mathrm{a}$ \\
LLMO6 & $28.7 \mathrm{a}$ & $36.3 \mathrm{bcde}$ & $59.3 \mathrm{ab}$ & $23.9 \mathrm{bcd}$ & $58.7 \mathrm{bc}$ & $100.6 \mathrm{bc}$ \\
LLMO7 & $23.7 \mathrm{bc}$ & $37.3 \mathrm{abc}$ & $56.0 \mathrm{cde}$ & $20.7 \mathrm{de}$ & $58.6 \mathrm{bc}$ & $167.0 \mathrm{a}$ \\
LLMO8 & $20.3 \mathrm{~d}$ & $36.0 \mathrm{bcde}$ & $56.3 \mathrm{cde}$ & $24.0 \mathrm{bcd}$ & $61.1 \mathrm{bc}$ & $133.9 \mathrm{ab}$ \\
LLMO9 & $25.3 \mathrm{~b}$ & $37.0 \mathrm{abcd}$ & $58.0 \mathrm{abc}$ & $26.3 \mathrm{ab}$ & $63.1 \mathrm{abc}$ & $111.7 \mathrm{bc}$ \\
LLMO10 & $22.7 \mathrm{bcd}$ & $37.0 \mathrm{abcd}$ & $55.3 \mathrm{de}$ & $28.1 \mathrm{a}$ & $60.3 \mathrm{bc}$ & $167.0 \mathrm{a}$ \\
LLMO11 & $22.7 \mathrm{bcd}$ & $36.3 \mathrm{bcde}$ & $57.7 \mathrm{abcd}$ & $26.1 \mathrm{ab}$ & $65.5 \mathrm{ab}$ & $90.6 \mathrm{bc}$ \\
\hline
\end{tabular}

${ }^{1}$ In column, means with the same letter are not significantly different (Tukey's test, $p \leq 0.05$ ).

In terms of the time it takes to reach flowering, fructifying and fruit maturity, the results coincide with those reported by Carrillo and Chávez [40] for wild tomato fruits: 16 to 29,30 to 40, and 56 to 71 days after transplant, respectively. In this research project, the values were 20 to 29,35 to 39 , and 54 from 60 days until flowering, fructifying and fruit maturation, respectively. This indicates that their behavior could be deemed similar to those classified as wild and semi-domesticated by the authors, given that they also behaved in a similar fashion to the wild germplasm described by Carrillo-Rodríguez et al. [41]. In terms of plant height at 30, 60 and 90 days after transplant, the results are also similar to those described by the aforementioned authors. These results indicate that the ruderal distribution of these genepools encompasses not only Mexico, but also Central America.

The tomato accessions described produced between 7 and 9 fruits per cluster and, up until the fifth bunch, some 35 to 41 fruits per plant were counted, with an average variation of 127.8 to $414.7 \mathrm{~g}$, based on an oscillation of 25.9 to 82.9 per cluster. LLMO1 presented the highest average weight for fruit $(10.5 \mathrm{~g})$, with longer $(2.9 \mathrm{~cm})$ and wider $(3.2 \mathrm{~cm})$ fruits; the smallest varied between 3.4 and $4.7 \mathrm{~g}$ and did not exceed $2.2 \mathrm{~cm}$ in length or diameter (Table 4). The largest fruits from LLMO1 coincided with those classified as semi-domesticated by Carrillo and Chávez [40], with weights varying between 10.6 and $18.1 \mathrm{~g}$ per fruit and equatorial and distal diameters greater than $2.5 \mathrm{~cm}$, taken from Oaxaca. 
As such, Álvarez-Hernández et al. [46] reported several similar groups to these in Michoacan, Mexico. On the other hand, small fruits weighing less than $4.8 \mathrm{~g}$ each were slightly heavier than the smallest fruits reported by Carrillo and Chávez [40], which weighed no more than $3 \mathrm{~g}$. However, the sizes were similar: 1.7 to $2.2 \mathrm{~cm}$ in length and 1.8 to $2.2 \mathrm{~cm}$ in width. The aforementioned authors reported lengths and diameters or widths no greater than $1.8 \mathrm{~cm}$. In Colombia, Médina and Lobo [47] determined the weight and sizes of tomato fruits of ruderal origin similar to those described in this paper, and these also coincide with a range of fruits from Sinaloa, Nayarit, Jalisco, Michoacan, Puebla, Veracruz and Oaxaca, Mexico, all of which were evaluated by Carrillo-Rodríguez et al. [41].

Plant height at 30, 60 and 90 days after transplant, days to flowering and maturating of fruits, and the number and weight of fruits per plant were the variables that the Pearson's correlation showed to be not significant $(\mathrm{r}<0.6, p \leq 0.05)$. In the principal component analysis (PCA) that followed, it was determined that two first principal components explained $98.5 \%$ of the total phenotypic variance. In Figure 1a, we can see that LLM01 presented precocity and lower plant height, while LLM03 showed the opposite behavior, and LLM02, LLM04, LLM06, and LLM09 presented intermediate conditions with respect to both extremes. In the first PC, the eigenvectors of major value were 0.02 , $0.05,1.00$ for plant height at 30,60 and 90 dat and $0.02,-0.01,-0.01$ and -0.02 for number and weight of fruits per plant, days to maturating of fruits, and days to flowering after transplanting, respectively. In the second PC, the eigenvector's values were $0.27,0.94,-0.06,-0.01,0.07,0.03$ and -0.17 for plant height at 30, 60 and 90 dat, days to flowering and maturating of fruits, and number and weight of fruits per plant, respectively. These patterns of phenotypic variation indicate that an important part of the differentiation of accessions is plant height, which is a reference to growth type from intermediate to indeterminate. This differentiation can also be observed in the cluster analysis (Figure 1b), where LLM01 differs significantly from the other two groups. The most descriptive variables and variance patterns described herein, are similar to those reported by Carrillo and Chávez [40] and Carrillo-Rodríguez et al. [41]; the characteristics of the plant and fruit are the determining factors in differentiating between semi-domesticated and wild tomato populations.

In the cluster analysis, three groups with contrasting characteristics were identified. Group I (LLM01) presents the largest size of round to square fruits $(3.2 \mathrm{~cm}$ width and $2.9 \mathrm{~cm}$ length), the fewest days for ripening (54), and the heaviest weight of fruits per cluster $(82.9 \mathrm{~g})$ and per plant $(414.7 \mathrm{~g})$. Group II includes the smallest and roundest fruits $(<2.0 \mathrm{~cm}$ in diameter and in length), an average production of $142.8 \mathrm{~g}$ per plant and $28.6 \mathrm{~g}$ per cluster, and plants with an average size of $100.8 \mathrm{~cm}$ (90 dat, days after transplant); however, this group was the slowest in terms of fruit maturity (58.6 dat). Group III encompasses the tallest plants $(162.6 \mathrm{~cm})$, an average production of fruits per plant of $168.2 \mathrm{~g}$, and an average weight of fruit per cluster of $33.6 \mathrm{~g}$ with quasi-spherical fruit $(2.0 \mathrm{~cm}$ in length and diameter), Figure $1 b$.

The variability of plant physiological and agromorphological traits suggested that the accessions evaluated only reflect a part of the total phenotypic variation of the wild tomato dispersion in El Salvador. For example, in an experiment on substrate evaluation in cherry tomato from Brazil, the plant heights at 61 days after transplant presented values from 126 to $130 \mathrm{~cm}$ [48], but heights ranged from 51.2 to $74.6 \mathrm{~cm}$ in the present study. These results are likely due to differences in cropping systems or the genotypes used. Similarly, in another evaluation of a collection of wild and cultivated cherry tomatoes in Colombia, Ceballos and Vallejo [11] determined an average of 96.1 fruits/plant and from 4.8 to $37.2 \mathrm{~g}$ of fruit, which in our study ranged from 35.1 to 41.9 fruits per plant at the fifth cluster and 3.3 to $10.5 \mathrm{~g}$ per fruit. It is necessary to note that there are difficulties related to comparability among studies; but taken together, each contribution provides useful information to formulate strategies of exploitation and germplasm preservation in the functioning of local requirements, opportunities and infrastructure in national agriculture research institutions. 
Table 4. Means comparison of flowers and fruits per cluster in eleven tomato accessions from El Salvador

\begin{tabular}{|c|c|c|c|c|c|c|c|c|}
\hline Pop. ID & $\begin{array}{c}\text { Flowers Per } \\
\text { Cluster }\end{array}$ & $\begin{array}{l}\text { Fruits Per } \\
\text { Cluster }\end{array}$ & $\begin{array}{l}\text { Fruits Per } \\
\text { Plant }\end{array}$ & $\begin{array}{l}\text { Fruit Weight } \\
\text { Per Cluster (g) }\end{array}$ & $\begin{array}{l}\text { Fruit Weight } \\
\text { Per Plant (g) }\end{array}$ & $\begin{array}{l}\text { Average Weight } \\
\text { Per Fruit (g) }\end{array}$ & $\begin{array}{l}\text { Fruit Length } \\
\text { (cm) }\end{array}$ & $\begin{array}{l}\text { Fruit Width } \\
\quad(\mathrm{cm})\end{array}$ \\
\hline LLMO1 & $8.8 \mathrm{a}^{1}$ & $7.9 \mathrm{abc}$ & $39.4 \mathrm{ab}$ & $82.9 a$ & $414.7 \mathrm{a}$ & $10.5 \mathrm{a}$ & $2.9 \mathrm{a}$ & $3.2 \mathrm{a}$ \\
\hline LLMO2 & $7.7 \mathrm{bc}$ & $7.7 \mathrm{abc}$ & $38.6 \mathrm{ab}$ & $25.9 c$ & $129.7 \mathrm{c}$ & $3.4 \mathrm{~b}$ & $1.8 \mathrm{c}$ & $2.2 \mathrm{~b}$ \\
\hline LLMO3 & $8.1 \mathrm{ab}$ & $8.1 \mathrm{ab}$ & $40.7 \mathrm{a}$ & $35.0 \mathrm{bc}$ & $175.2 \mathrm{bc}$ & $4.3 \mathrm{~b}$ & $1.9 \mathrm{c}$ & $2.0 \mathrm{bcd}$ \\
\hline LLMO4 & $7.0 \mathrm{c}$ & $7.0 \mathrm{c}$ & $35.1 \mathrm{~b}$ & $26.4 \mathrm{c}$ & $132.0 \mathrm{c}$ & $3.8 \mathrm{~b}$ & $1.9 \mathrm{c}$ & $1.9 \mathrm{~cd}$ \\
\hline LLMO5 & $8.4 \mathrm{ab}$ & $8.4 \mathrm{a}$ & $41.9 \mathrm{a}$ & $39.5 \mathrm{~b}$ & $197.5 \mathrm{~b}$ & $4.7 \mathrm{~b}$ & $1.9 \mathrm{c}$ & $2.0 \mathrm{bcd}$ \\
\hline LLMO6 & $7.7 \mathrm{bc}$ & $7.7 \mathrm{abc}$ & $38.3 \mathrm{ab}$ & $25.6 c$ & $127.8 \mathrm{c}$ & $3.3 \mathrm{~b}$ & $1.7 \mathrm{c}$ & $1.8 \mathrm{~d}$ \\
\hline LLMO7 & $7.9 \mathrm{abc}$ & $7.9 \mathrm{abc}$ & $39.6 \mathrm{ab}$ & $34.6 \mathrm{bc}$ & $172.9 \mathrm{bc}$ & $4.4 \mathrm{~b}$ & $1.9 \mathrm{c}$ & $1.9 \mathrm{~cd}$ \\
\hline LLMO8 & $7.0 \mathrm{c}$ & $7.0 \mathrm{c}$ & $34.9 \mathrm{~b}$ & $29.4 \mathrm{bc}$ & $147.1 \mathrm{bc}$ & $4.2 \mathrm{~b}$ & $2.2 \mathrm{~b}$ & $2.2 \mathrm{~b}$ \\
\hline LLMO9 & $8.2 \mathrm{ab}$ & $8.2 \mathrm{ab}$ & $40.8 \mathrm{a}$ & $33.6 \mathrm{bc}$ & $167.9 \mathrm{bc}$ & $4.1 \mathrm{~b}$ & $1.8 \mathrm{c}$ & $2.0 \mathrm{bcd}$ \\
\hline LLMO10 & $7.9 \mathrm{abc}$ & $7.9 \mathrm{abc}$ & $39.3 \mathrm{ab}$ & $29.7 \mathrm{bc}$ & $148.5 \mathrm{bc}$ & $3.8 \mathrm{~b}$ & $1.8 \mathrm{c}$ & $1.9 \mathrm{~cd}$ \\
\hline LLMO11 & $8.1 \mathrm{ab}$ & $8.1 \mathrm{ab}$ & $41.1 \mathrm{a}$ & $31.3 \mathrm{bc}$ & $156.6 \mathrm{bc}$ & $3.8 \mathrm{~b}$ & $1.9 \mathrm{c}$ & $1.8 \mathrm{~d}$ \\
\hline
\end{tabular}

${ }^{1}$ In column, means with the same letter are not significantly different (Tukey's test, $p \leq 0.05$ ). 


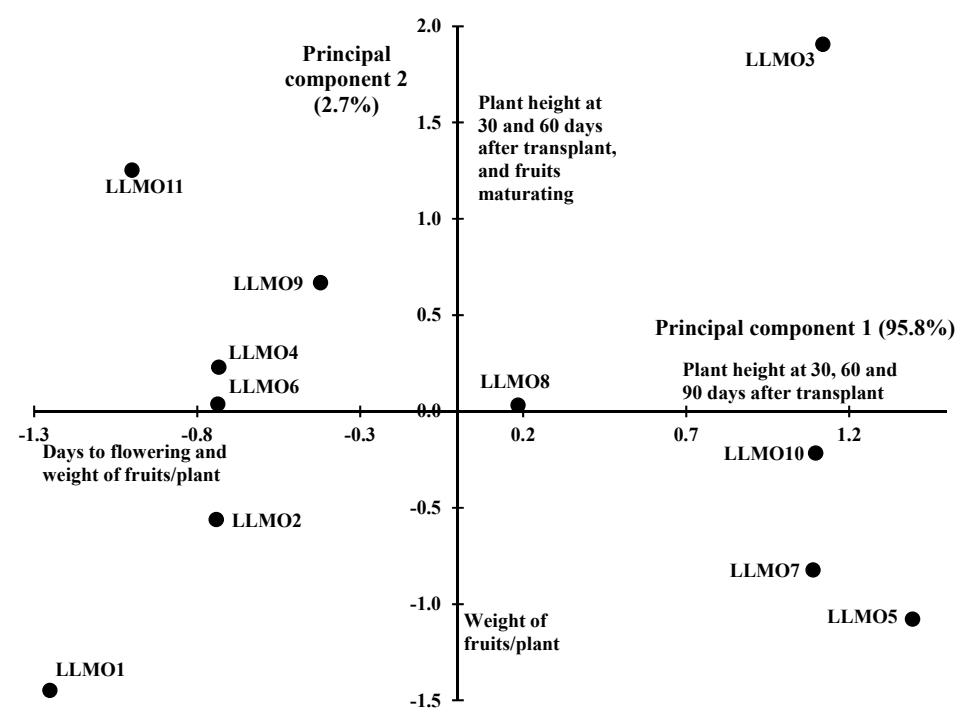

(a)

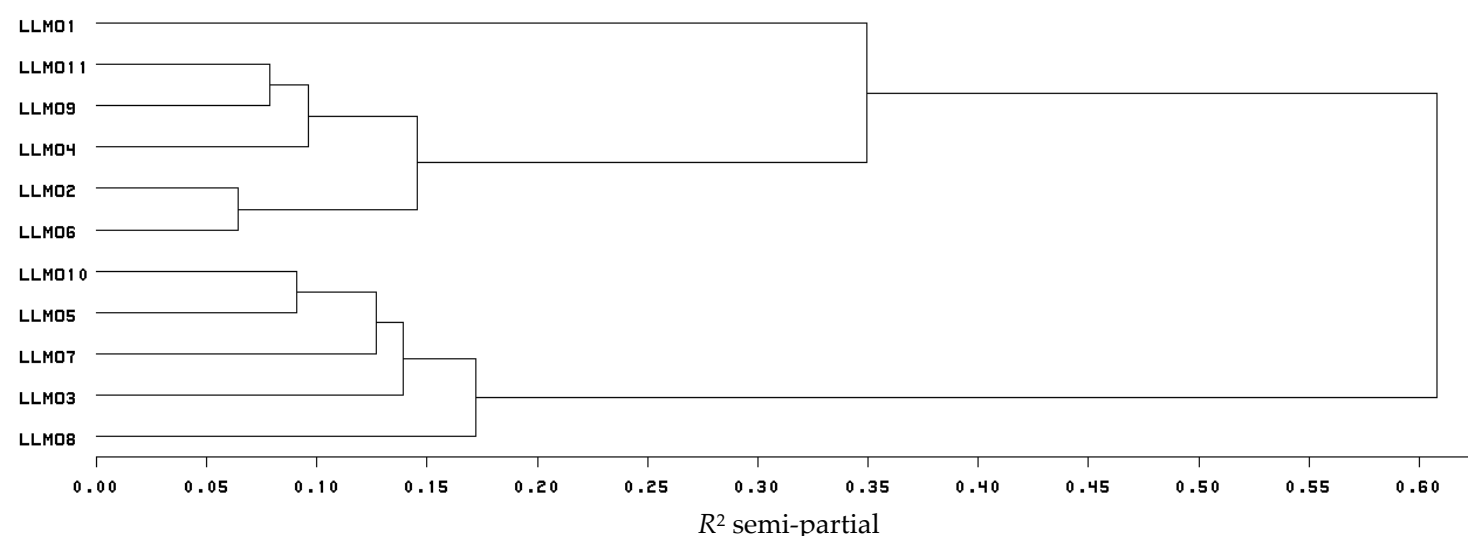

(b)

Figure 1. Dispersion of tomato accessions from El Salvador, based on two first principal components (a) with variables associated to higher eigenvector values, and (b) with hierarchical clustering by Ward's method, with regard to agromorphological traits.

\subsection{Mineral Content in Tomato Fruits}

In the analysis of variance, significant differences $(p<0.05)$ were detected among the accessions for all minerals except $\mathrm{Cu}$. The phenotypic variation expressed as a variation coefficient was $17.2 \%$ for $\mathrm{Mn}$ and $24.3 \%$ for $\mathrm{Ca}$ (Table 5). Not only do the accessions differ in terms of the agromorphological traits evaluated, but they also differ in terms of the mineral content of the fruit. As such, it is important to state that all the plants from each population from which the analyzed fruits were harvested was handled in a uniform manner within the greenhouse.

The mineral content of the fruit revealed that the population with the largest fruits (LLM01) consistently had the lowest content of $\mathrm{Ca}, \mathrm{Mg}, \mathrm{P}, \mathrm{S}, \mathrm{Fe}, \mathrm{Zn}$ and $\mathrm{Mn}$, while the accessions with the lowest content of two or more macro- and micro-elements were LLM07, LLM08, LLM10 and LLM11. On the other hand, the accessions with the highest concentrations of one or more elements were those with the smallest fruit: LLM02, LLM04, LLM06 and LLM09 (Table 6). We can infer that the concentration of minerals is related to the amount of water in the fruit and the absorption and translocation of minerals in the plant, among other factors. It is important to highlight the fact that the mineral content of tomato fruits depends on a range of factors: species, genotype, planting or harvesting season, crop substrate 
(if applicable), conventional or organic crop system, nitrogen content, and greenhouse or field growing conditions, among others $[13,32,33,35,36]$.

Table 5. Square means significance of mineral content in fruits of eleven tomato accessions from El Salvador, Central America.

\begin{tabular}{ccccc}
\hline \multirow{2}{*}{ Mineral Content in Fruit } & \multicolumn{3}{c}{ Sources of Variation } & \multirow{2}{*}{ CV (\%) } \\
\cline { 2 - 4 } & Repetition & Populations & Error & \\
\hline $\mathrm{Ca}$ & $548.7^{* *}$ & $165.6^{* *}$ & 20.7 & 24.3 \\
$\mathrm{~K}$ & $23,477.7^{* *}$ & $7787.0^{*}$ & 3177.2 & 17.5 \\
$\mathrm{Mg}$ & $102.0^{* *}$ & $46.0^{* *}$ & 12.6 & 22.0 \\
$\mathrm{Mn}$ & $0.020^{* *}$ & $0.008^{* *}$ & 0.003 & 17.2 \\
$\mathrm{P}$ & $756.9^{* *}$ & $563.4^{* *}$ & 116.3 & 21.8 \\
$\mathrm{~S}$ as SO 4 & $13.6^{\mathrm{NS}}$ & $80.1^{* *}$ & 8.8 & 21.4 \\
$\mathrm{Na}$ & $0.02^{\mathrm{NS}}$ & $1.25^{* *}$ & 0.31 & 18.4 \\
$\mathrm{Cu}$ & $0.086^{* *}$ & $0.010^{\mathrm{NS}}$ & 0.01 & 22.2 \\
$\mathrm{Fe}$ & $0.046^{*}$ & $0.068^{* *}$ & 0.014 & 17.4 \\
$\mathrm{Zn}$ & $0.107^{* *}$ & $0.044^{* *}$ & 0.016 & 21.1 \\
\hline
\end{tabular}

NS , * and ${ }^{* *}=$ not significant $(p>0.05)$, significant at $p<0.05$ and $p<0.01$, respectively; $C V=$ coefficient of variation.

Table 6. Mean comparisons for minerals in the fruit of eleven tomato accessions from El Salvador.

\begin{tabular}{|c|c|c|c|c|c|c|}
\hline \multirow{2}{*}{ Pop. ID/Macro-Elements } & $\mathrm{Ca}$ & $\mathbf{K}$ & Mg & $\mathbf{P}$ & S & $\mathrm{Na}$ \\
\hline & \multicolumn{6}{|c|}{ mg/100 g of Dry Weight } \\
\hline LLM01 & $9.2 \mathrm{~d}^{1}$ & $281.7 \mathrm{ab}$ & $11.3 \mathrm{c}$ & $32.8 \mathrm{c}$ & $32.4 \mathrm{c}$ & $12.8 \mathrm{a}$ \\
\hline LLM02 & $23.4 \mathrm{ab}$ & $311.4 \mathrm{ab}$ & $20.4 \mathrm{a}$ & $57.5 \mathrm{ab}$ & $35.7 \mathrm{bc}$ & $7.2 \mathrm{abc}$ \\
\hline LLM03 & $15.1 \mathrm{~cd}$ & $345.2 \mathrm{ab}$ & $13.4 \mathrm{bc}$ & $47.1 \mathrm{abc}$ & $41.5 \mathrm{bc}$ & $11.1 \mathrm{abc}$ \\
\hline LLM04 & $25.5 \mathrm{a}$ & $348.0 \mathrm{a}$ & $18.3 \mathrm{ab}$ & $62.1 \mathrm{a}$ & $37.2 \mathrm{bc}$ & $6.4 \mathrm{c}$ \\
\hline LLM05 & $22.2 \mathrm{abc}$ & $326.7 \mathrm{ab}$ & $16.3 \mathrm{abc}$ & $45.3 \mathrm{abc}$ & $47.4 \mathrm{bc}$ & $10.7 \mathrm{abc}$ \\
\hline LLM06 & $21.2 \mathrm{abc}$ & $350.8 \mathrm{a}$ & $17.6 \mathrm{ab}$ & $59.1 \mathrm{ab}$ & $65.0 \mathrm{a}$ & $6.7 \mathrm{bc}$ \\
\hline LLM07 & $15.2 \mathrm{~cd}$ & $310.7 \mathrm{ab}$ & $16.1 \mathrm{abc}$ & $46.4 \mathrm{abc}$ & $47.7 \mathrm{~b}$ & $12.7 \mathrm{ab}$ \\
\hline LLM08 & $21.4 \mathrm{abc}$ & $327.0 \mathrm{ab}$ & $17.6 \mathrm{ab}$ & $43.8 \mathrm{abc}$ & $34.5 \mathrm{bc}$ & $10.7 \mathrm{abc}$ \\
\hline LLM09 & $15.6 \mathrm{bcd}$ & $346.9 \mathrm{ab}$ & $16.4 \mathrm{abc}$ & $57.5 \mathrm{ab}$ & $36.9 \mathrm{bc}$ & $11.5 \mathrm{abc}$ \\
\hline LLM10 & $14.6 \mathrm{~cd}$ & $251.6 \mathrm{~b}$ & $13.4 \mathrm{bc}$ & $44.0 \mathrm{abc}$ & $33.9 \mathrm{bc}$ & $8.7 \mathrm{abc}$ \\
\hline LLM11 & $20.0 \mathrm{abc}$ & $303.1 \mathrm{ab}$ & $15.2 \mathrm{abc}$ & $42.4 \mathrm{bc}$ & $35.9 \mathrm{bc}$ & $5.8 \mathrm{c}$ \\
\hline \multirow{2}{*}{ Pod. ID/Micro-Elements } & $\mathrm{Fe}$ & $\mathrm{Zn}$ & Mn & $\mathrm{Cu}$ & & \\
\hline & \multicolumn{4}{|c|}{$\mathrm{mg} / 100 \mathrm{~g}$ of Dry Weight } & & \\
\hline LLM01 & $0.283 c^{1}$ & $0.178 \mathrm{c}$ & $0.079 \mathrm{~b}$ & $0.149 \mathrm{a}$ & & \\
\hline LLM02 & $0.838 \mathrm{a}$ & $0.386 \mathrm{abc}$ & $0.128 \mathrm{ab}$ & $0.215 \mathrm{a}$ & & \\
\hline LLM03 & $0.396 \mathrm{bc}$ & $0.347 \mathrm{abc}$ & $0.080 \mathrm{~b}$ & $0.235 \mathrm{a}$ & & \\
\hline LLM04 & $0.612 \mathrm{ab}$ & $0.378 \mathrm{abc}$ & $0.146 \mathrm{a}$ & $0.256 \mathrm{a}$ & & \\
\hline LLM05 & $0.380 \mathrm{bc}$ & $0.410 \mathrm{abc}$ & $0.088 \mathrm{ab}$ & $0.166 \mathrm{a}$ & & \\
\hline LLM06 & $0.603 \mathrm{ab}$ & $0.439 \mathrm{ab}$ & $0.115 \mathrm{ab}$ & $0.179 \mathrm{a}$ & & \\
\hline LLM07 & $0.415 \mathrm{bc}$ & $0.361 \mathrm{abc}$ & $0.092 \mathrm{ab}$ & $0.270 \mathrm{a}$ & & \\
\hline LLM08 & $0.423 \mathrm{bc}$ & $0.231 \mathrm{bc}$ & $0.088 \mathrm{ab}$ & $0.233 \mathrm{a}$ & & \\
\hline LLM09 & $0.494 \mathrm{abc}$ & $0.582 \mathrm{a}$ & $0.113 \mathrm{ab}$ & $0.187 \mathrm{a}$ & & \\
\hline LLM10 & $0.471 \mathrm{abc}$ & $0.335 \mathrm{abc}$ & $0.094 \mathrm{ab}$ & $0.239 \mathrm{a}$ & & \\
\hline LLM11 & $0.582 \mathrm{ab}$ & $0.359 \mathrm{abc}$ & $0.105 \mathrm{ab}$ & $0.246 \mathrm{a}$ & & \\
\hline
\end{tabular}

${ }^{1}$ In column, means with the same letter are not significantly different (Tukey's test, $p \leq 0.05$ ).

Ca content in this research project ranged from 9.2 to $25.5 \mathrm{mg} / 100 \mathrm{~g}$ of dry weight, which was slightly higher than that reported by Hernández-Suárez et al. [33] for beefsteak and saladette tomatoes from Tenerife, Spain, which ranged from 5.3 to $8.2 \mathrm{mg} / 100 \mathrm{~g}$ of wet sample and were within the interval reported by Aghili et al. [35] of 9.6 to $10.7 \mathrm{mg} / 100$ of wet sample. The high values were similar to those reported for the fruits of S. lycopersicum, with an average of $23.6 \mathrm{mg} / 100 \mathrm{~g}$, and below 
those reported for S. pimpinellifolium, S. cheesmaniae and S. habrochaites ( $>37 \mathrm{mg} / 100 \mathrm{~g}$ ) registered by Fernández-Ruiz et al. [13]. K, Mg, P, S and Na content follow the same pattern, coinciding with or contradicting the values reported by several authors. However, there is consistently a high level of phenotypic variation regarding the macro-elements found in the fruit; this is useful for future programs geared toward the genetic improvement of fruit quality given that the contents, reported herein for small fruits, are close to and, in some cases, very similar to the values reported for a range of wild species and cherry tomato fruits [12,13].

With regard to the micro-elements relevant to human health, such as Fe and $\mathrm{Zn}$, the variation was between 0.28 and 0.84 and 0.18 and $0.58 \mathrm{mg} / 100 \mathrm{~g}$ of wet sample, respectively. These values are below those reported for $S$. pimpinellifolium, S. cheesmaniae and $S$. habrochaites in terms of Fe content ( 0.95 to $1.17 \mathrm{mg} / 100 \mathrm{~g}$ of sample), but within the range for $\mathrm{Zn}(0.17$ to $0.70 \mathrm{mg} / 100 \mathrm{~g})$ reported by Fernández-Ruiz et al. [13]. However, both elements were higher than the values reported by Hernández-Suárez et al. [33] for commercial tomato varieties: 0.16 to $0.27 \mathrm{mg} / 100 \mathrm{~g}$ for Fe, and 0.06 to $0.09 \mathrm{mg} / 100 \mathrm{~g}$ for $\mathrm{Zn}$. This indicates that the tomato accessions described here can be considered an important genetic source for improving the quality of fruit in El Salvador, and, as such, can help avoid dependence on the importation of high-quality commercial varieties.

The content of $\mathrm{Ca}, \mathrm{K}, \mathrm{Cu}, \mathrm{Fe}, \mathrm{Zn}$ and $\mathrm{S}$ exhibited independence, because their correlations were not significant $(r<0.6, p<0.05)$; these elements were used in the principal component analysis, in which the two first principal components explained $99.2 \%$ of the total phenotypic variation. In particular, Ca, $\mathrm{Fe}, \mathrm{K}$ and $\mathrm{S}$ in the fruits were the minerals that had the highest descriptive value for total variance based on the eigenvectors' values. In the first PC, Ca, K, Cu Fe and S presented eigenvectors of 0.078, 0.996, $<0.001,0.001,0.002$ and 0.048, respectively, and in the second PC, eigenvectors of 0.997, $-0.077,0.003$, 0.024, 0.001 and -0.016 , respectively. In Figure 2a, we can observe at least two patterns of dispersion: in the upper-right section, the accessions LLM06, LLM04, LLM08 and LLM05, were associated with higher Fe, Ca, K or S content; on the opposite side were the accessions LLM01 and LLM07. The last pattern clearly shows the differentiation of LLM01 and LLM10, found along the extreme left-hand and lower side, which were characterized as having lower values in different micro- and macro-minerals.

In the cluster analysis, four phenotypic groups were observed based on the mineral content of the fruit (Figure 2b). Group I (LLM01) presented the lowest values for all elements except for Na $(12.8 \mathrm{mg} / 100 \mathrm{~g})$, which was the highest value of all of the populations. The extreme opposite of group I are those accessions with the highest content of all the minerals evaluated, belonging to group IV (LLM05, LLM06 and LLM09), except for their very low values of Na (6.8 mg/100 g). Between these two groups are II and III, whose values for mineral content range between those of group I and group IV. For example, group II (LLM03, LLM07, LLM08 and LLM10) presented high values of K, P, Na, Zn and Mn, while group III presented high values of $\mathrm{Ca}, \mathrm{K}, \mathrm{P}, \mathrm{Na}, \mathrm{Fe}, \mathrm{Zn}$ and $\mathrm{Mg}$ (Table 6 and Figure 2b).

The mineral content in tomatoes provides insights into the differences among the accessions in terms of the uptake, translocation, and accumulation of mineral elements in the fruit, despite there being only one cycle of evaluation. Nevertheless, cherry tomato fruits, when consumed fresh, can make an important contribution to the diets of rural families, based on the levels of minerals reported here, primarily on the basis of trace elements and some macro-elements such as $\mathrm{K}, \mathrm{Mg}$, $\mathrm{P}$ and $\mathrm{Na}$, according human requirements [49]. The results of the mineral evaluations of the tomato accessions in this study are similar to the reports of other authors $[13,14,16]$, and we think that the cherry tomato in El Salvador and other countries is an option for helping decrease the mineral deficiencies affecting human health. For example, results suggest that $100 \mathrm{~g}$ of fresh tomato can supply from 5 to $15 \%$ of the daily $\mathrm{K}, \mathrm{P}, \mathrm{Mg}$, $\mathrm{Mn}$ and $\mathrm{Cu}$ requirements, according to White and Broadley [49]. In this sense, the accessions started fruit maturation 54 to 60 days after transplant and presented yields per plant from 132.0 to $414.7 \mathrm{~g}$, which means access to food for low-income families two months after transplant, as well as being a minerals source and a strategic resource to be cultivated in home gardens or small plots. In addition, the utilization of such accessions by farmers will help to conserve on-farm this genetic resource [50], 
and with complementary evaluations it will be possible to identify the accessions with stable yields and high fruit quality across environments.

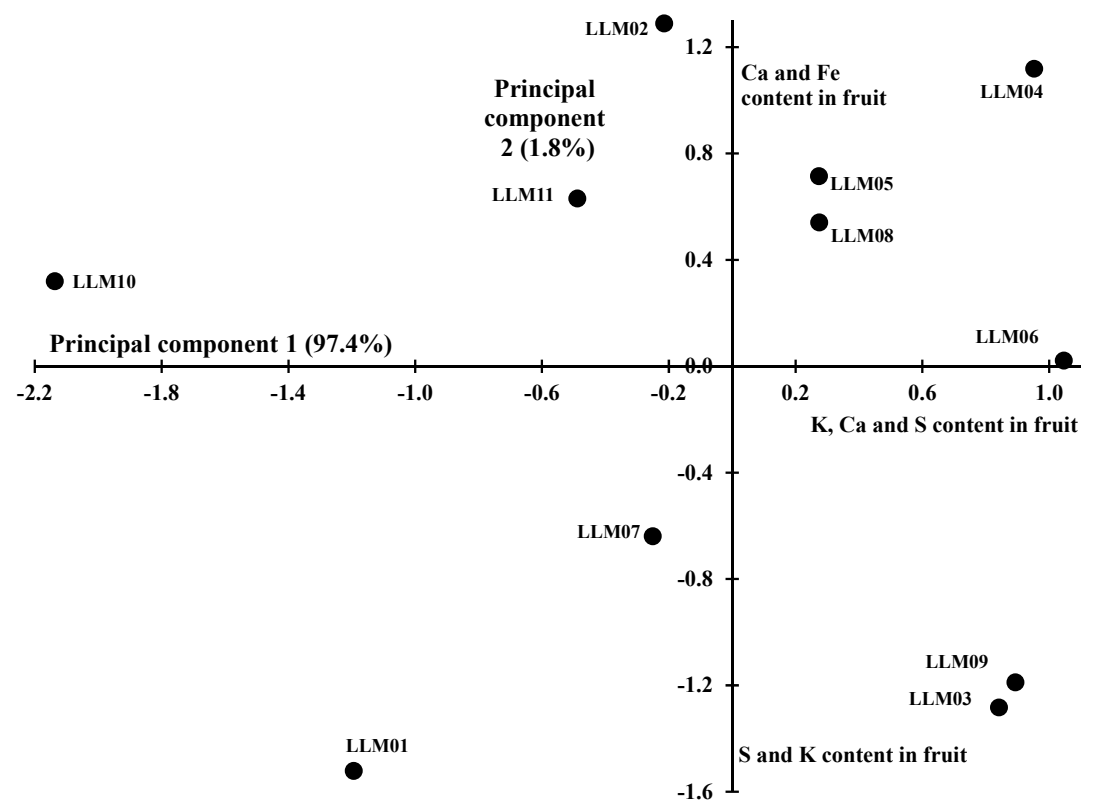

(a)

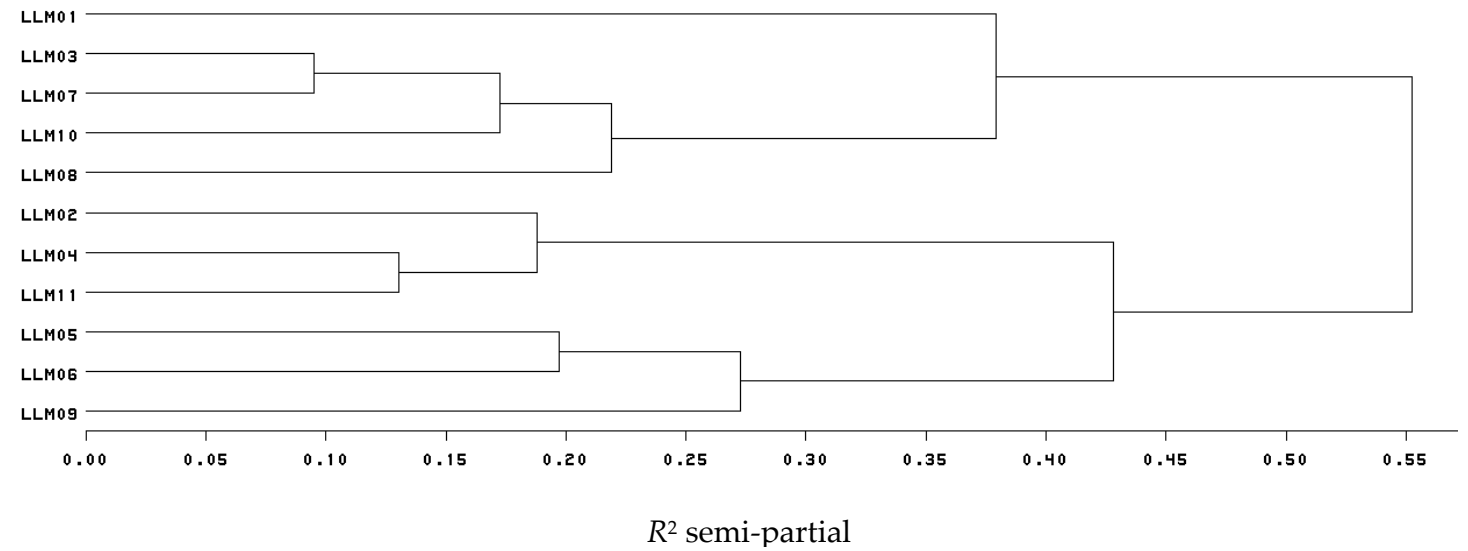

(b)

Figure 2. Dispersion of tomato accessions from El Salvador, based on two first principal components (a) with variables associated to higher eigenvector values, and (b) with hierarchical clustering by Ward's method, regarding mineral content in tomato fruits.

Finally, when we evaluated the correlation among fruit traits and mineral content, we found a significant negative correlation $(t$-test, $p<0.05)$ from -0.67 to -0.71 among the average weights of fruits per cluster and per plant, and the average weight per fruit with $\mathrm{Ca}, \mathrm{Mg}, \mathrm{Fe}$ and $\mathrm{P}$, and a positive correlation of the same fruit traits with $\mathrm{Na}(0.63)$. Zn content in fruits presented a significant negative correlation $(p<0.05)$ with fruit width $(-0.63)$ and length $(-0.76)$. This result indicates that the mineral content in cherry and medium-sized tomatoes is influenced by fruit density and fruit changes in clusters and plants. This is likely a reference to the time elapsed from the set of fruit to maturity, which is less time than for the processing of a larger-sized commercial tomato. White and Broadley [51] suggest that new agronomic and breeding strategies intended to increase the mineral concentration in fruits or edible tissues necessitate the combination of agronomic traits and high nutrient contents that are feasibly attained. 


\section{Conclusions}

Of the eleven tomato accessions from El Salvador, significant differences $(p<0.01)$ were found in the plants and the phenological and fruit characteristics evaluated. LLM01 presented the largest size ( $2.9 \mathrm{~cm}$ long and $3.2 \mathrm{~cm}$ wide) and fruit weight ( $10.5 \mathrm{~g} /$ fruit). Plant heights at 30,60 and 90 days after transplant, days to flowering and maturation of fruits, and the number and weight of fruits per plant were the variables of major descriptive value to the total phenotypic variation among the tomato accessions, which were classified in three groups based on the indicators of growth type, precocity to flowering and maturation of fruits, and production of fruits. In terms of the mineral content in the fruits, the accessions differed significantly $(p<0.01)$ in all evaluated elements apart from $\mathrm{Cu}$ content. $\mathrm{Ca}, \mathrm{K}, \mathrm{Cu}, \mathrm{Fe}, \mathrm{Zn}$ and $\mathrm{S}$ content in the fruits were the most descriptive values for total variance, and were classified in four phenotypically divergent groups. Again, LLM01 registered the lowest content of Mg, P, S, Fe, Zn and Mn. In general, the accessions LLM02, LLM04, LLM06 and LLM09 presented the highest values of micro- and macro-elements. The weights of the fruits per cluster and per plant and the average weight per fruit presented significant negative correlations with $\mathrm{Ca}, \mathrm{Mg}, \mathrm{Fe}$ and $\mathrm{P}$, and a positive correlation of the same fruit traits with $\mathrm{Na}$. The mineral content in the tomato accessions are influenced by fruit density and fruit changes in the clusters and plants.

Acknowledgments: The authors are grateful for the financial support provided by the Instituto Politecnico Nacional (project nos. 20170781 and 20170841), and COFAA-IPN and EDI-IPN fellows.

Author Contributions: J.L.C.-S., L.R.L.-M. and J.C.C.-R. performed the research, data analysis and wrote the paper; A.M.V.-G. and E.N.A.-B. contributed with laboratory analysis.

Conflicts of Interest: The authors declare no conflict of interest.

\section{References}

1. Jenkins, J.A. The origin of the cultivated tomato. Econ. Bot. 1948, 2, 379-392. [CrossRef]

2. Rick, C.M. Genetic variability in tomato species. Plant Mol. Biol. Rep. 1983, 1, 81-87. [CrossRef]

3. Peralta, I.E.; Spooner, D.M.; Knapp, S. Taxonomy of wild tomatoes and their relatives (Solanum sect. Lycopersicoides, sect. Juglandifolia, sect. Lycopersicon; Solanaceae). Syst. Bot. Mon. 2008, 84, 1-186.

4. Grandillo, S.; Chetelat, R.; Knapp, S.; Spooner, D.; Peralta, I.; Cammreri, M.; Perez, O.; Termolino, P.; Chiusano, M.L.; Ercolano, M.R.; et al. Solanum sect. Lycopersicon. In Wild Crop Relatives: Genomic and Breeding Resources Vegetables; Kole, C., Ed.; Springer: New York, NY, USA, 2011; pp. 129-215.

5. Ortiz, R.; Izquierdo, J. Yield stability differences among tomato genotypes grown in Latin America and the Caribbean. HortScience 1994, 29, 1175-1177.

6. Ortiz, R.; Crossa, J.; Vargas, M.; Izquierdo, J. Studying the effect of environmental variables on the genotype x environment interaction of tomato. Euphytica 2007, 153, 119-134. [CrossRef]

7. Terzopoulus, P.J.; Walters, S.A.; Bebeli, P.J. Evaluation of Greek tomato landraces populations for heterogeneity of horticultural traits. Eur. J. Hort. Sci. 2009, 74, 24-29.

8. Mazzucato, A.; Ficcadenti, N.; Caioni, M.; Mosconi, P.; Piccinini, E.; Sanampudi, V.R.R.; Sestili, S.; Ferrari, V. Genetic diversity and distinctiviness in tomato (Solanum lycopersicum L.) landraces: The Italian case study of 'A pera Abruzzese'. Sci. Hort. 2010, 125, 55-62. [CrossRef]

9. Cebolla-Cornejo, J.; Roselló, S.; Nuez, F. Phenotypic and genetic diversity of Spanish tomato landraces. Sci. Hort. 2013, 162, 150-164. [CrossRef]

10. Lenucci, M.S.; Cadinu, D.; Taurino, M.; Piro, G.; Dalessandro, G. Antioxidant composition in cherry and high-pigment tomato cultivars. J. Agric. Food Chem. 2006, 54, 2606-2613. [CrossRef] [PubMed]

11. Ceballos, N.; Vallejo, F.A. Evaluating the fruit production and quality of cherry tomato (Solanum lycopersicum var. cerasiforme). Rev. Fac. Nac. Agr. 2012, 65, 6593-6604.

12. Bressy, F.C.; Brito, G.B.; Barbosa, I.S.; Teixeira, L.S.G.; Korn, M.G.A. Determination if trace element concentrations in tomato samples at different stages of maturation by ICP OES and ICP-MS following microwave-assisted digestion. Microchem. J. 2013, 109, 145-149. [CrossRef] 
13. Fernández-Ruiz, V.; Olives, A.I.; Cámara, M.; Sánchez-Mata, M.C.; Esperanza-Torija, M. Mineral and trace elements content in 30 accessions of tomato fruits (Solanum lyopersicum L.) and wild relatives (Solanum pimpinellifolium L.; Solanum cheesmaniae L. Riley, and Solanum habrochaites S. Knapp \& D.M. Spooner). Biol. Trace Elem. Res. 2011, 141, 329-339. [PubMed]

14. Guil-Guerrero, J.L.; Rebolloso-Fuentes, M.M. Nutrient composition and antioxidant activity of eight tomato (Lycopersicon esculentum) varieties. J. Food Comp. Anal. 2008, 22, 123-129. [CrossRef]

15. Hernández-Suárez, M.; Peña-Méndez, E.; Rodríguez-Galdón, B.; Rodríguez-Rodríguez, E.; Díaz-Romero, C. Influence of agronomic variables on quality of tomato fruits. Agric. Sci. 2011, 2, 424-431.

16. Oyetayo, F.L.; Ibitoye, M.F. Phytochemical and nutrient/antinutrient interactions in cherry tomato (Lycopersicum esculentum) fruits. Intern. J. Adv. Biol. Res. 2012, 2, 681-684.

17. Rick, C.M. Potential genetic resources in tomato species: Clues from observations in native habitats. In Genes, Enzymes and Populations; Srb, A., Ed.; Plenum Press: New York, NY, USA, 1973; pp. 255-269.

18. Hoisington, D.; Khairallah, M.; Reeves, T.; Ribaut, J.-M.; Skovmand, B.; Taba, S.; Warburton, M. Plant genetic resources: What can they contribute toward increased crop productivity? Proc. Natl. Acad. Sci. USA 1999, 96, 5937-5943. [CrossRef] [PubMed]

19. Terzopoulus, P.J.; Bebeli, P.J. Phenotypic diversity in Greek tomato (Solanum lycopersiucm L.) landraces. Sci. Hort. 2010, 126, 138-144. [CrossRef]

20. Koutsika-Sortitiou, M.; Mylonas, I.; Tsivelikas, A.; Traka-Mavrona, E. Compensation studies on the tomato landraces 'Tomataki Santorinis'. Sci. Hort. 2016, 198, 78-85. [CrossRef]

21. García-Martínez, S.; Corrado, G.; Ruiz, J.J.; Rao, R. Diversity and structure of a simple of traditional Italian and Spanish tomato accessions. Genet. Resour. Crop Evol. 2013, 60, 789-798. [CrossRef]

22. Galiana-Balaguer, L.; Rosello, S.; Nuez, F. Characterization and selection of balanced sources of variability for breeding tomato (Lycopersicon) internal quality. Genet. Resour. Crop Evol. 2006, 53, 907-923. [CrossRef]

23. Sadashiva, A.T.; Christopher, M.G.; Krithika, T.K. Genetic enhancement of tomato crop for abiotic stress tolerance. In Climate-Resilient Horticulture: Adaptation and Mitigation Strategies; Sinh, H.P., Rao, N.K.S., Shivashankar, K.S., Eds.; Springer: New Delhi, India, 1973; pp. 113-124.

24. Ashraf, A.; Foolad, M.R. Crop breeding for salt tolerance in the era of molecular markers and marker-assisted selection. Plant Breed. 2013, 132, 10-20. [CrossRef]

25. Hartman, J.B.; St Clair, D.A. Combining ability for beet armyworm, Spodoptera exigua, resistance and horticultural traits of selected Lycopersicon pennellii-derived inbred backcross lines of tomato. Plant Breed. 1999, 118, 523-530. [CrossRef]

26. Cervantes-Moreno, R.; Rodríguez-Pérez, J.E.; Carrillo, C.; Sahagún-Castellanos, J.; Rodríguez-Guzmán, E. Tolerancia de 26 colectas de tomates nativos de México al nematodo Meloidogyne incognita (Kofoid y White) Chitwood. Rev. Chapingo Ser. Hort. 2014, 20, 5-18. [CrossRef]

27. Bauchet, G.; Cause, M. Genetic diversity in tomato (Solanum lycopersicum) and its wild relatives. In Genetic Diversity in Plants; Caliskan, M., Ed.; InTech Europe: Rijeka, Croatia, 2012; pp. 133-162.

28. Hernández-Bautista, A.; Lobato-Ortiz, R.; Cruz-Izquierdo, S.; García-Zavala, J.J.; Chávez-Servia, J.L. Variación fenotípica, heterosis y heredabilidad de una cruza interespecífica de jitomate. Interciencia 2014, 39, 327-332.

29. Van den Heuvel, T.; Rene, R.J.; Gremmen, B.; van woerkum, C.; van Trijp, H. Consumers' images regarding genomics as a tomato breeding technology: "Maybe it can provide a more tasty tomato". Euphytica 2008, 159, 207-216. [CrossRef]

30. Méndez-Infante, I.; Vera-Guzmán, A.M.; Chávez-Servia, J.L.; Carrillo-Rodríguez, J.C. Quality of fruits in Mexican tomato (Lycopersicon esculentum Mill.) landraces. VITAE-Rev. Fac. Quím. Farm. 2011, 18, $26-32$.

31. Luna-Guevara, M.L.; Delgado-Alvarado, A. Importancia, contribución y estabilidad de antioxidantes en frutos y productos de tomate (Solanum lycopersicum L.). Av. Investig. Agrop. 2014, 18, 51-66.

32. Gundersen, V.; McCall, D.; Bechmann, I.E. Comparison of major and trace element concentrations in Danish greenhouse tomatoes (Lycopersicum esculentum cv. Aromata F1) cultivated in different substrates. J. Agric. Food Chem. 2001, 49, 3808-3815. [CrossRef] [PubMed]

33. Hernández-Suárez, M.; Rodríguez-Rodríguez, E.M.; Díaz-Romero, C. Mineral and trace element concentrations in cultivars of tomatoes. Food Chem. 2007, 104, 489-499. [CrossRef]

34. Kelly, S.D.; Bateman, A.S. Comparison of mineral concentrations in commercially grown organic and conventional crops-tomatoes (Lycopersicon esculentum) and lettuces (Lactuca sativa). Food Chem. 2010, 119, 738-745. [CrossRef] 
35. Aghili, F.; Khoshgoftarmnesh, A.H.; Afyuni, M.; Mobil, M. Mineral and ascorbic acid concentrations of greenhouse- and field-grown vegetables: Implications for human health. Int. J. Veg. Sci. 2012, 18, 64-77. [CrossRef]

36. Borgognone, D.; Colla, G.; Rouphael, Y.; Cardarelli, M.; Rea, E.; Schwarz, D. Effect of nitrogen form and nutrient solution $\mathrm{pH}$ on growth and mineral composition of self-grafted and grafted tomatoes. Sci. Hortic. 2013, 149, 61-69. [CrossRef]

37. Corrado, G.; Piffanelli, P.; Caramante, M.; Coppola, M.; Rao, R. SNP genotyping reveals genetic diversity between cultivated landraces and contemporary varieties of tomato. BMB Genom. 2013, 14, 835. [CrossRef] [PubMed]

38. Cebolla-Cornejo, J.; Roselló, S.; Valcárcel, M.; Serrano, E.; Beltrán, J.; Nuez, F. Evaluation of genotypes and environments effects on tatste aroma flavor components of Spanish fresh tomato varieties. J. Agric. Food Chem. 2011, 59, 2440-2450. [CrossRef] [PubMed]

39. IPGRI; AVRDC; CATIE. Descriptors for Capsicum (Capsicum spp.); International Plant Genetic Resources Institute: Rome, Italy; Asian Vegetable Research and Development Center: Taipei, Taiwan; Centro Agronómico Tropical de Investigación y Enseñanza: Turrialba, Costa Rica, 1995; pp. 1-50.

40. Carrillo, J.C.; Chávez, J.L. Caracterización agromorfológica de muestras de tomate de Oaxaca. Rev. Fitotec. Mex. 2010, 33, 1-6.

41. Carrillo-Rodríguez, J.C.; López-Mendoza, H.; Chávez-Servia, J.L.; Rodríguez-Guzmán, E.; Sánchez-Peña, P.; Lobato-Ortiz, R. Phenotypic divergences on growth and productivity of wild and semidomesticated cherry tomato grown under greenhouse conditions. Acta Hortic. 2012, 947, 375-380. [CrossRef]

42. AOAC. Official Methods of Analysis of the Association of Official Analytical Chemists, 15th ed.; Association of Official Analytical Chemist: Washington, DC, USA, 1990; Volume 2, pp. $27-42$.

43. Peralta, I.E.; Spooner, D.M. History, origin and early cultivation of tomato (Solanaceae). In Genetic Improvement of Solanaceous Crops, Vol. 2. Tomato; Razdan, M.K., Mattoo, A.K., Eds.; Science Publishers: Enfield, CT, USA, 2007; pp. 1-27.

44. Chetelat, R.T. Revised list of wild species stocks. Tomato Gen. Coop. Rep. 2004, 54, 52-76.

45. Chetelat, R.T. Revised list of miscellaneous stocks. Tomato Gen. Coop. Rep. 2006, 56, 37-59.

46. Álvarez-Hernández, J.C.; Cortez-Madrigal, H.; García-Ruiz, I. Exploración y caracterización de poblaciones silvestres de jitomate (Solanaceae) en tres regiones de Michoacán, México. Polibotánica 2009, 28, 139-159.

47. Medina, C.I.; Lobo, M. Variabilidad morfológica en el tomate pajarito (Lycopersicum esculentum var. cerasiforme), precursor del tomate cultivado. Rev. Corpoica 2001, 3, 39-50.

48. Costa, E.; da Silva, F.F.; Duarte, E.; Barbosa, D.; Zoz, T.; Zuffo, A.M. Cherry tomato production on different organic substrates under protected environment conditions. Aust. J. Crop Sci. 2018, 12, 87-92. [CrossRef]

49. White, P.J.; Broadley, M.R. Biofortifying crops with essential mineral elements. Trend Plant Sci. 2005, 10, 586-593. [CrossRef] [PubMed]

50. Rocchi, L.; Paolotti, L.; Cortina, C.; Boggia, A. Conservation of landrace: The key role of the value for agrobiodiversity conservation. An application on ancient tomatoes varieties. Agric. Agric. Sci. Procedia 2016, 8, 307-316. [CrossRef]

51. White, P.J.; Broadley, M.R. Biofortification of crops with seven mineral elements often lacking in human diets-iron, zinc, copper, calcium, magnesium, selenium and iodine. New Phytol. 2009, 182, 49-84. [CrossRef] [PubMed]

(C) 2018 by the authors. Licensee MDPI, Basel, Switzerland. This article is an open access article distributed under the terms and conditions of the Creative Commons Attribution (CC BY) license (http:/ / creativecommons.org/licenses/by/4.0/). 